\title{
POTENTIAL OIL PALM GENETIC MATERIALS DERIVED FROM INTROGRESSION OF GERMPLASM (MPOB-Nigeria, MPOB-Zaire and MPOB-Cameroon accessions) TO ADVANCED (AVROS) BREEDING POPULATION
}

\author{
NOR AZWANI, A B*; FADILA, A M*; MOHD DIN, A*; RAJANAIDU, N*; NORZIHA, A*; SUZANA, ${ }^{*}$; \\ MARHALIL, $\mathrm{M}^{*}$; ZULKIFLI, $\mathrm{Y}^{*}$ and KUSHAIRI, ${ }^{*}$
}

\begin{abstract}
The narrow genetic base of current oil palm planting materials is the main obstacle in oil palm breeding and population improvements. However, genetic variability can be widened through introgression of advanced materials with selected oil palm germplasm. Thus, tenera performance was evaluated from 14 tenera $x$ pisifera involving MPOB-Nigeria (MPOB-NGA), MPOB-Cameroon (MPOB-CMR) and MPOB-Zaire (MPOB-ZRE) crosses with Algemene Vereniging van Rubberplanters ter Oostkust van Sumatra (AVROS) progenies. Analysis of variance between groups showed significant differences in fresh fruit bunch (FFB) yield and its components, bunch quality components and most of the vegetative traits studied. Strong and positive correlations of FFB and oil to bunch $(O / B)$ with oil yield (OY) suggested that oil yield can be improved by increasing FFB yield or O/B. Broad-sense heritability estimates varied from a low of $20.56 \%$ (FFB yield) to a high of $100 \%$ (shell to fruit ratio). Both PK 1858 (MPOB-ZRE $x$ AVROS) and PK 1867 (MPOB-NGA $x$ AVROS) progenies have been identified as potential sources of pisifera for selection due to their promising results in most of the desired traits.
\end{abstract}

Keywords: germplasm advanced breeding population, introgression.

Received: 22 March 2019; Accepted: 13 February 2020; Published online: 25 September 2020.

\section{INTRODUCTION}

Oil palm (Elaeis guineensis Jacq.) is the largest produced and traded vegetable oil in the global oils and fats market. It has the lowest production costs of all vegetable oils and production has been estimated to reach 240 million tonnes by 2050 (Corley, 2009). As the second largest producer and exporter of palm oil, Malaysia has a huge role to play in fulfilling the increasing global need for vegetable

Malaysian Palm Oil Board,

6 Persiaran Institusi, Bandar Baru Bangi,

43000 Kajang, Selangor, Malaysia.

E-mail: nor.azwani@mpob.gov.my oils and fats. In 2018, Malaysia contributed about $33 \%$ or 16.49 million tonnes of global palm oil exports (Kushairi, 2019). The global demand for edible vegetable oils has grown in recent decades and palm oil production has expanded rapidly to meet that demand. The Malaysian oil palm industry is supported by strategic policies as well as research and development activities by the Malaysian Palm Oil Board (MPOB) in developing high yielding planting materials. However, introduction of new exotic germplasm is necessary to widen the genetic pool of oil palm for further improvements. This realisation inspired MPOB to explore new oil palm genetic materials from its centre of origin in Africa (Hardon, 1974; Rajanaidu, 1994). 
In 1973, the first prospection was conducted in Nigeria for MPOB-Nigeria (MPOB-NGA) collection (Rajanaidu et al., 2008). The MPOB-Cameroon (MPOB-CMR) and MPOB-Zaire (MPOB-ZRE) oil palm germplasm was jointly collected with Unilever in 1984. These three earliest germplasm collections have been field planted at the MPOB Research Station, Kluang, Johor, Malaysia and have been extensively evaluated for yield, bunch quality traits, fatty acid composition, vegetative measurement and physiological parameters. The MPOB-NGA germplasm provided several interesting traits for breeding, particularly dwarfness, high iodine value and high kernel content (Rajanaidu et al., 2000). High oleic acid was also a trait of this germplasm (Isa et al., 2006). Elite MPOB-NGA materials of high oil yield, high iodine value $(>60)$ and low stature were distributed to members of the industry for progeny testing and introgression into the current breeding materials to initiate new breeding lines for commercial seed production. MPOB has discovered the potential of oil palm collections to develop planting materials via selecting the outstanding MPOB-NGA dura and pisifera palms to increase the level of genetic variability in current Deli dura and tenera/pisifera (Rajanaidu et al., 1996).

MPOB-CMR and MPOB-ZRE were among the germplasm collections which produced oils with high vitamin E (Kushairi et al., 2004). Selected palms from both MPOB-CMR and MPOB-ZRE populations have also shown partial resistance to Ganoderma in nursery screening experiments (Idris et al., 2005). MPOB-CMR and MPOB-ZRE germplasm collections also possessed more than $20 \%$ crude protein in the kernel (Noh et al., 2014). In addition, MPOB-CMR genetic material was listed as an MPOB germplasm with low lipase and high bunch index (BI) traits, the latter an essential character for the selection of high yielding materials (Maizura et al., 2008; Fadila et al., 2016).

The AVROS has been widely distributed as the source of pisifera parent by major seed producers worldwide. It is noted for its high oil yield and vigorous growth-conferring attributes. In addition, they exhibit high mesocarp to fruit $(\mathrm{M} / \mathrm{F})$, oil to bunch $(\mathrm{O} / \mathrm{B})$ ratios and trunk height increment (HTI) (Lee and Yeow, 1985; Rajanaidu et al., 1986; Rao et al., 1999; Noh et al., 2012). Therefore, the aim of this study was to determine the performance of teneras from the tenera $\mathrm{x}$ pisifera $(\mathrm{T} \times \mathrm{P})$ crosses, involving MPOB-NGA, MPOB-CMR and MPOBZRE introgressed into AVROS. Pisifera palms would also be identified from the outstanding progenies for progeny testing with advanced breeding populations.

\section{MATERIALS AND METHODS}

A total of 14 progenies derived from TxP crosses of four MPOB-NGA x AVROS, seven MPOB-CMR $x$ AVROS and three MPOB-ZRE $x$ AVROS were planted in a triangular planting system at $9 \mathrm{~m}$ apart in a Randomised Completely Block Design (RCBD) with 16 palms per plot (progeny) with two replications (Table 1). The progenies were planted in Trial 0.351 at the MPOB Research Station, Keratong, Pahang, Malaysia in 1996. The site in Keratong is characterised by the Serdang soil series and average annual rainfall recorded here is below $2000 \mathrm{~mm}$.

\section{Data Collection}

The fresh fruit bunch (FFB) yield data was recorded for each individual palm in both replications at an interval of three rounds per month. FFB yield is the sum of bunch weight (BWT) while average bunch weight $(\mathrm{ABW})$ is the quotient between FFB and bunch number (BNO). BWT and $\mathrm{BNO}$ are recorded for each palm per harvesting round, starting from 36 months after field planting for seven consecutive years (2003-2009). Bunch analysis is conducted to estimate the oil and kernel content of bunches, so that oil yields can be calculated (Corley and Tinker, 2016). The bunch analysis method developed by Blaak et al. (1963) and modified by Rao et al. (1983) was used to determine oil extraction and fruit quality components, such as mesocarp to fruit $(\% \mathrm{M} / \mathrm{F})$, shell to fruit $(\% \mathrm{~S} / \mathrm{F})$, oil to dry mesocarp $(\% \mathrm{O} / \mathrm{DM})$, fruit to bunch $(\% \mathrm{~F} / \mathrm{B})$, oil to bunch $(\mathrm{O} / \mathrm{B})$, kernel to bunch $(\% \mathrm{~K} / \mathrm{B})$, kernel to fruit $(\% \mathrm{~K} / \mathrm{F})$, oil yield $(\mathrm{OY})$ and total economic product (TEP). Three to five bunches were sampled from each palm from 2003-2009. To avoid seasonal variation, ripe bunches with one to 10 loose fruits were randomly sampled at intervals of at least three months from the previous sampling palm (Rao, 1987). One round of vegetative measurement was conducted in 2004, which is eight years after field planting as proposed by Corley and Breure (1981). Palm height was measured from the ground level to the base of frond number 41. HTI was calculated using the formula: height increment $/$ year $=$ (height at year $t) /(\mathrm{t}-2)$, where $t$ is the age of the palm (Breure and Powell, 1987). Morphological traits such as frond production (FP), petiole cross- section (PCS), rachis length (RL), leaflet length (LL), leaflet number (LN), HTI, leaflet area (LA), leaflet area index (LAI) diameter (DIA) were also recorded following methods established by Breure and Powell, (1987).

\section{Statistical Analysis}

The data on bunch yield, FFB, ABW and $\mathrm{BNO}$, bunch quality characters and vegetative measurement was analysed using Statistical Analytical System (SAS version 9.2). The analysis of variance (ANOVA) and correlations for all traits 
POTENTIAL OIL PALM GENETIC MATERIALS DERIVED FROM INTROGRESSION OF GERMPLASM (MPOB-Nigeria, MPOB-Zaire and MPOB-Cameroon accessions) TO ADVANCED (AVROS) BREEDING POPULATION

TABLE 1. LIST OF (TxP) Tenera PROGENIES IN TRIAL 0.351 AT MPOB RESEARCH STATION, KERATONG

\begin{tabular}{|c|c|c|c|c|c|c|c|}
\hline No. & Materials & Progeny & $\begin{array}{c}\text { Female } \\
\text { parent }(\mathrm{A})\end{array}$ & $\begin{array}{c}\text { Male } \\
\text { parent (B) }\end{array}$ & $\mathbf{A}$ & B & Pedigree B \\
\hline 1 & NGA x AVROS & PK 1595 & $0.151 / 330$ & $0.182 / 357$ & NGA 17.02 & MS 2182 & $0.79 / 11 \times 0.79 / 221$ \\
\hline 2 & NGA $x$ AVROS & PK 1768 & $0.151 / 638$ & $0.182 / 357$ & NGA 11.18 & MS 2182 & $0.79 / 11 \times 0.79 / 221$ \\
\hline 3 & NGA x AVROS & PK 1867 & $0.149 / 11745$ & $0.174 / 304$ & NGA 16.02 & MS 1258 & $0.79 / 196 \times 0.79 / 116$ \\
\hline 4 & NGA x AVROS & PK 2005 & $0.149 / 11526$ & $0.174 / 211$ & NGA 12.01 & MS 1436 & $0.79 / 374 \times 0.79 / 27$ \\
\hline 5 & CMR x AVROS & PK 1776 & $0.218 / 1336$ & $0.174 / 282$ & CMR 19.02 & MS 1410 & $0.79 / 45 \times 0.79 / 286$ \\
\hline 6 & CMR x AVROS & PK 1885 & $0.219 / 844$ & $0.174 / 211$ & CMR 19.02 & MS 2184 & $0.79 / 231 \times 0.79 / 281$ \\
\hline 7 & CMR x AVROS & PK 1904 & $0.219 / 299$ & $0.182 / 25$ & CMR 19.02 & MS 2184 & $0.79 / 231 \times 0.79 / 281$ \\
\hline 8 & CMR x AVROS & PK 1917 & $0.219 / 299$ & $0.174 / 211$ & CMR 19.02 & MS 1436 & $0.79 / 374 \times 0.79 / 27$ \\
\hline 9 & CMR x AVROS & PK 1922 & $0.218 / 1336$ & $0.174 / 211$ & CMR 19.02 & MS 1436 & $0.79 / 374 \times 0.79 / 27$ \\
\hline 10 & CMR x AVROS & PK 1963 & $0.218 / 1006$ & $0.174 / 211$ & CMR 29.01 & MS 1436 & $0.79 / 374 \times 0.79 / 27$ \\
\hline 11 & CMR x AVROS & PK 1971 & $0.219 / 299$ & $0.174 / 282$ & CMR 19.02 & MS 1410 & $0.79 / 45 \times 0.79 / 286$ \\
\hline 12 & ZRE x AVROS & PK 1815 & $0.211 / 341$ & $0.182 / 410$ & CMR 30.01 & MS 2188 & $0.79 / 372 \times 0.79 / 583$ \\
\hline 13 & ZRE x AVROS & PK 1858 & $0.211 / 341$ & $0.174 / 955$ & CMR 30.01 & MS 1436 & $0.79 / 374 \times 0.79 / 27$ \\
\hline 14 & ZRE x AVROS & PK 1923 & $0.221 / 739$ & $0.174 / 955$ & CMR 30.01 & MS 1436 & $0.79 / 374 \times 0.79 / 27$ \\
\hline 15 & $\mathrm{SC}(\mathrm{DxP})$ & PK 1589 & $0.175 / 912$ & $0.200 / 812$ & MS 1421 & MS 3138 & $0.95 / 6195 \times 0.79 / 6165$ \\
\hline
\end{tabular}

studied were calculated using SAS (Table 2). The Duncan New Multiple Range Test (DNMRT) was used for comparison between progeny means. Broad-sense heritability statistics were estimated for each character using variance components. The variance analysis for the estimation of broadsense heritability was processed from the variance component procedure (PROC VARCOMP) of SAS version 9.2 using the formula:

$$
h^{2}{ }_{\text {B }}=\frac{\alpha^{2} \mathrm{f}}{\alpha^{2} \mathrm{f}+\alpha^{2} w f}
$$

where $\alpha^{2} \mathrm{f}=$ variance between family, $\alpha^{2} \mathrm{wf}=$ variance within family. In full-sib families, $2 h_{B}^{2}$ equals broad -sense heritability (Falconer and Mackay, 1996).

\section{RESULTS AND DISCUSSION}

\section{Yield and Yield Components}

Yield and its components for all groups of crosses comprising MPOB-NGA x AVROS, MPOBZRE $x$ AVROS and MPOB-CMR $x$ AVROS are shown in Table 3. ANOVA between groups showed significant differences for FFB, BNO and ABW. A wide range in yield and its components was observed among these progenies, which may be important for oil palm breeding and selection. This high variability was also reported by Marhalil et al. (2013) on their study in genetic variability of yield and vegetative traits of MPOB-NGA dura x AVROS pisifera. Junaidah et al. (2011) also reported high performance variability in teneras derived from Deli dura and different pisifera sources.

TABLE 2. OUTLINE OF ANOVA AND VARIANCE COMPONENTS ESTIMATION

\begin{tabular}{lccc}
\hline Source & $d f$ & Mean square & EMS \\
\hline Replication $(\mathrm{r})$ & $\mathrm{r}-1$ & MS1 & $\sigma^{2} \mathrm{w}+\mathrm{n}^{\prime} \sigma_{\mathrm{rp}}^{2}+\mathrm{n}^{\prime} \mathrm{p}^{2} \mathrm{r}$ \\
Progeny $(\mathrm{p})$ & $\mathrm{p}-1$ & $\mathrm{MS} 2$ & $\sigma^{2} \mathrm{w}+\mathrm{n}^{\prime} \sigma_{\mathrm{rp}}^{2}+\mathrm{n}^{\prime} \mathrm{r}_{\mathrm{p}}^{2}$ \\
Replication x progeny $(\mathrm{r} \times \mathrm{p})$ & $(\mathrm{r}-1)(\mathrm{p}-1)$ & $\mathrm{MS} 3$ & $\sigma^{2} \mathrm{w}+\mathrm{n}^{\prime} \sigma_{\mathrm{rp}}^{2}$ \\
Error $(\mathrm{w})$ & $\mathrm{rp}\left(\mathrm{n}^{\prime}-1\right)$ & MS4 & $\sigma^{2} \mathrm{w}$ \\
\hline
\end{tabular}

Note: $\mathrm{n}^{\prime}$ - harmonic mean for palms; $\mathrm{r}$ - number of replication; $\mathrm{p}$ - number of progeny or genotype; $d f$ - degrees of freedom. 
TABLE 3. ANOVA OF Tenera PROGENIES FOR YIELD AND YIELD COMPONENTS

\begin{tabular}{|c|c|c|c|c|}
\hline Source of variance & $d f$ & $\begin{array}{c}\text { FFB } \\
\left(\mathrm{kg} \mathrm{palm}^{-1} \mathrm{yr}^{-1}\right)\end{array}$ & $\begin{array}{c}\text { BNO } \\
\text { (bunches palm }{ }^{-1} \mathrm{yr}^{-1} \text { ) }\end{array}$ & $\begin{array}{c}\text { ABW } \\
\left(\mathrm{kg} \mathrm{bunches}^{-1}\right)\end{array}$ \\
\hline Between groups & 2 & $4314.83^{* *}$ & $22.39^{*}$ & $14.29^{* *}$ \\
\hline Within groups & 178 & 1088.75 & 7.35 & 11.74 \\
\hline
\end{tabular}

Note: * **, Indicate significant at $\mathrm{P} \leq 0.05, \mathrm{P} \leq 0.01$, respectively; FFB - fresh fruit bunch; BNO - bunch number; ABW - average bunch weight.

Further analysis indicated that both MPOBNGA $x$ AVROS and MPOB-ZRE $x$ AVROS crosses exhibited statistically significant differences in their BNO and ABW, while MPOB-CMR x AVROS demonstrated significant difference in their FFB yields (Table 4). Among the three crosses, MPOBZRE $x$ AVROS registered the highest FFB yield $(\mathrm{P}<0.05)$ (Table 5). On the other hand, FFB and ABW production from both MPOB-NGA x AVROS and MPOB-CMR $x$ AVROS were not significantly different from MPOB-ZRE x AVROS. MPOB-CMR $x$ AVROS also produced a lower BNO $(\mathrm{P}<0.05)$ than MPOB-NGA $x$ AVROS and MPOB-ZRE. These results were in line with the findings of Rajanaidu et al. (2000), whereby the population means of FFB yield and its components for MPOB-ZRE was slightly higher than MPOB-CMR.

Among the progenies, PK 1963 from MPOBCMR $\times$ AVROS produced the highest FFB yield of $189.59 \mathrm{~kg} \mathrm{palm}^{-1} \mathrm{yr}^{-1}$, which was slightly higher than the best progeny from MPOB-ZRE $x$ AVROS $\left(181.16 \mathrm{~kg} \mathrm{palm}^{-1} \mathrm{yr}^{-1}\right)$. However, the lowest FFB yield was also recorded from MPOB-CMR $x$ AVROS by PK 1885 which produced only $139.26 \mathrm{~kg}^{\text {palm}}{ }^{-1}$ $\mathrm{yr}^{-1}$ of FFB.

The PK 1768 from MPOB-NGA $x$ AVROS produced a low BNO of 8.80 bunches palm ${ }^{-1} \mathrm{yr}^{-1}$ but recorded a significantly higher ABW of 19.42 $\mathrm{kg}$ bunch $^{-1}$. Among the MPOB-ZRE $x$ AVROS progenies, PK 1858 produced the highest $A B W$ of 13.16 bunches palm ${ }^{-1} \mathrm{yr}^{-1}$. The low BNO with high ABW observed for MPOB-NGA crosses was also observed for introgressed MPOB-NGA dura x Deli dura (Noh et al., 2014). In contrast, Isa et al. (2008) suggested that MPOB-NGA materials were categorised as high $\mathrm{BNO}$ and low $\mathrm{ABW}$.

\section{Bunch Quality Components}

Significant difference was observed for all bunch quality component traits between the three groups of crosses (Table 6). However, when compared between the families within each cross, statistically significant difference was only observed in OY for all three crosses (Table 7). For MPOB-NGA $x$ AVROS cross, statistically significant difference was observed between families for M/F, S/F, O/B and TEP while significant difference in $\mathrm{M} / \mathrm{F}, \mathrm{K} / \mathrm{F}$, $\mathrm{S} / \mathrm{F}, \mathrm{K} / \mathrm{B}$, and $\mathrm{KY}$ between families was observed in the MPOB-CMR $x$ AVROS cross. MPOB-ZRE $x$ AVROS exhibited significant difference only for the $\mathrm{O} / \mathrm{DM}$ trait. The significant difference for these traits indicates high genetic variation for these characters. High genetic variability has also been observed in bunch quality traits in Deli dura $\mathrm{x}$ AVROS pisifera (Noh et al., 2010).

Further analysis showed that MPOB-NGA $x$ AVROS demonstrated the highest means in traits $\mathrm{M} / \mathrm{F}$ and $\mathrm{O} / \mathrm{B}$, but with significantly lower $\mathrm{S} / \mathrm{F}$, $\mathrm{K} / \mathrm{B}$ and $\mathrm{K} / \mathrm{Y}$. On the other hand, MPOB-ZRE $\mathrm{x}$ AVROS produced excellent values for $\mathrm{F} / \mathrm{B}, \mathrm{KY}$ with a high TEP of $40.34 \mathrm{~kg} \mathrm{palm}^{-1} \mathrm{yr}^{-1}$ (Table 8). PK 1867

TABLE 4. ANOVA OF MPOB-NGA x AVROS, MPOB-CMR x AVROS AND MPOB-ZRE x AVROS Tenera PROGENIES FOR YIELD AND YIELD COMPONENTS

\begin{tabular}{llcccc}
\hline Materials & Source of variance & $d f$ & FFB & BNO & ABW \\
\hline \multirow{2}{*}{ MPOB-NGA x AVROS } & Between family & 3 & $674.01^{\text {ns }}$ & $27.54^{* *}$ & $95.09^{* *}$ \\
& Within family & 57 & 1300.11 & 5.96 & 7.80 \\
MPOB-CMR x AVROS & Between family & 6 & $3642.16^{* *}$ & $8.81^{\text {ns }}$ & $7.52^{\text {ns }}$ \\
& Within family & 79 & 856.88 & 7.03 & 10.96 \\
MPOB-ZRE x AVROS & Between family & 2 & $50.20^{\text {ns }}$ & $27.17^{*}$ & $48.23^{*}$ \\
& Within family & 31 & 903.94 & 7.23 & 11.36 \\
\hline
\end{tabular}

Note: ${ }^{*}{ }^{* *}$, and $\mathrm{ns}$ indicate significant at $\mathrm{P} \leq 0.05, \mathrm{P} \leq 0.01$ and not significant, respectively; FFB - fresh fruit bunch; BNO bunch number; ABW - average bunch weight. 
TABLE 5. MEAN PERFORMANCE OF Tenera PROGENIES FOR YIELD AND ITS COMPONENTS

\begin{tabular}{|c|c|c|c|c|c|}
\hline \multirow[b]{2}{*}{ Material } & \multirow[b]{2}{*}{ Progeny code } & \multirow[b]{2}{*}{ Pedigree } & \multicolumn{3}{|c|}{ Mean for year 2003-2009 } \\
\hline & & & $\begin{array}{c}\text { FFB } \\
\left(\mathrm{kg} \mathrm{palm}^{-1}\right. \\
\left.\mathrm{yr}^{-1}\right)\end{array}$ & $\begin{array}{c}\text { BNO } \\
\text { (bunches palm } \\
\mathrm{yr}^{-1} \text { ) }\end{array}$ & $\begin{array}{c}\text { ABW } \\
\left.\text { (kg bunches }^{-1}\right)\end{array}$ \\
\hline \multirow[t]{5}{*}{ MPOB-NGA x AVROS } & PK 1595 & $0.151 / 330 \times 0.182 / 357$ & $154.81^{\mathrm{bc}}$ & $12.01^{\mathrm{ba}}$ & $13.32^{\mathrm{d}}$ \\
\hline & PK 1768 & $0.151 / 638 \times 0.182 / 357$ & $170.24^{\mathrm{bac}}$ & $8.80^{\mathrm{d}}$ & $19.42^{\mathrm{a}}$ \\
\hline & PK 1867 & $0.149 / 11745 \times 0.174 / 304$ & $164.54^{\mathrm{bac}}$ & $10.25^{\mathrm{bdc}}$ & $16.15^{\mathrm{bdc}}$ \\
\hline & PK 2005 & $0.149 / 11526 \times 0.174 / 211$ & $155.98^{\mathrm{bc}}$ & $11.77^{\mathrm{ba}}$ & $13.83^{\mathrm{d}}$ \\
\hline & & Mean & $162.44^{\mathrm{b}}$ & $10.54^{\text {ba }}$ & $15.91^{\mathrm{a}}$ \\
\hline \multirow[t]{8}{*}{ MPOB-CMR x AVROS } & PK 1776 & $0.218 / 1336 \times 0.174 / 282$ & $162.95^{\mathrm{bac}}$ & $10.80^{\text {bdac }}$ & $15.94^{\mathrm{bdc}}$ \\
\hline & PK 1885 & $0.219 / 844 \times 0.174 / 211$ & $139.26^{c}$ & $9.12^{\mathrm{dc}}$ & $15.58^{\text {bdc }}$ \\
\hline & PK 1904 & $0.219 / 299 \times 0.182 / 25$ & $164.81^{\mathrm{bac}}$ & $9.71^{\mathrm{bdc}}$ & $17.55^{\text {ba }}$ \\
\hline & PK 1917 & $0.219 / 299 \times 0.174 / 211$ & $164.64^{\mathrm{bac}}$ & $9.53^{\mathrm{bdc}}$ & $17.38^{\text {ba }}$ \\
\hline & PK 1922 & $0.218 / 1336 \times 0.174 / 211$ & $143.30^{c}$ & $9.23^{\mathrm{dc}}$ & $17.00^{\mathrm{bac}}$ \\
\hline & PK 1963 & $0.218 / 1006 \times 0.174 / 211$ & $189.59^{\mathrm{a}}$ & $11.40^{\text {bac }}$ & $17.01^{\mathrm{bac}}$ \\
\hline & PK 1971 & $0.219 / 299 \times 0.174 / 282$ & $156.99^{\mathrm{bc}}$ & $10.07^{\mathrm{bdc}}$ & $16.10^{\text {bdc }}$ \\
\hline & & Mean & $160.39^{b}$ & $9.89^{b}$ & $16.78^{\mathrm{a}}$ \\
\hline \multirow[t]{4}{*}{ MPOB-ZRE x AVROS } & PK 1815 & $0.211 / 341 \times 0.182 / 410$ & $177.07^{\text {ba }}$ & $10.38^{\mathrm{bdc}}$ & $17.58^{\text {ba }}$ \\
\hline & PK 1858 & $0.211 / 341 \times 0.174 / 955$ & $181.16^{\text {ba }}$ & $13.16^{\mathrm{a}}$ & $14.06^{\mathrm{dc}}$ \\
\hline & PK 1923 & $0.221 / 739 \times 0.174 / 955$ & $178.92^{\mathrm{ba}}$ & $10.38^{\mathrm{bdc}}$ & $17.99^{\text {ba }}$ \\
\hline & & Mean & $178.79^{\mathrm{a}}$ & $11.20^{\mathrm{a}}$ & $16.65^{\mathrm{a}}$ \\
\hline SC (DxP) & PK 1589 & $0.175 / 912 \times 0.200 / 812$ & 142.45 & 8.09 & 17.91 \\
\hline Grand mean & & & 167.21 & 10.54 & 16.45 \\
\hline
\end{tabular}

Note: FFB - fresh fruit bunch; BNO - bunch number; ABW - average bunch weight; Means with different small letter(s) in the same column are significantly different $(\mathrm{P}<0.05)$ from Duncan New Multiple Range Test (DNMRT).

TABLE 6. ANOVA OF Tenera PROGENIES FOR BUNCH QUALITY COMPONENTS

\begin{tabular}{|c|c|c|c|c|c|c|c|c|c|c|c|}
\hline $\begin{array}{l}\text { Source of } \\
\text { variance }\end{array}$ & $d f$ & $\begin{array}{l}\mathrm{M} / \mathrm{F} \\
(\%)\end{array}$ & $\begin{array}{l}\mathrm{K} / \mathrm{F} \\
(\%)\end{array}$ & $\begin{array}{l}\mathrm{S} / \mathrm{F} \\
(\%)\end{array}$ & $\begin{array}{c}\text { O/DM } \\
(\%)\end{array}$ & $\begin{array}{l}\mathrm{F} / \mathrm{B} \\
(\%)\end{array}$ & $\begin{array}{l}\mathrm{O} / \mathrm{B} \\
(\%)\end{array}$ & $\begin{array}{l}\mathrm{K} / \mathrm{B} \\
(\%)\end{array}$ & $\begin{array}{c}\text { OY } \\
\left(\mathrm{kg} \mathrm{palm}^{-1}\right. \\
\left.\mathrm{yr}^{-1}\right)\end{array}$ & $\begin{array}{c}\mathrm{KY} \\
\left(\mathrm{kg} \mathrm{palm}^{-1}\right. \\
\left.\mathrm{yr}^{-1}\right)\end{array}$ & $\begin{array}{c}\text { TEP } \\
\left(\mathrm{kg} \mathrm{palm}^{-1}\right. \\
\left.\mathrm{yr}^{-1}\right)\end{array}$ \\
\hline Between group & 2 & $907.46^{* *}$ & $129.60^{* *}$ & $386.03^{\star *}$ & $22.40^{* *}$ & $354.48^{* *}$ & $85.59^{* *}$ & $63.11^{* *}$ & $185.09^{*}$ & $195.07^{\star *}$ & $224.61^{*}$ \\
\hline Within group & 178 & 29.05 & 4.84 & 13.87 & 5.78 & 40.63 & 11.00 & 2.71 & 60.48 & 8.51 & 76.44 \\
\hline
\end{tabular}

Note: *, **, and ns indicate significant at $\mathrm{P} \leq 0.05, \mathrm{P} \leq 0.01$ and not significant, respectively; $\mathrm{M} / \mathrm{F}$ - mesocarp to fruit ratio; $\mathrm{K} / \mathrm{F}$ - kernel to fruit ratio; $\mathrm{S} / \mathrm{F}$ - shell to fruit ratio; $\mathrm{O} / \mathrm{DM}$ - oil to dry mesocarp ratio; $\mathrm{F} / \mathrm{B}$ - fruit to bunch ratio; $\mathrm{O} / \mathrm{B}$ - oil to bunch ratio; $\mathrm{K} / \mathrm{B}$ - kernel to bunch ratio; OY - oil yield; KY - kernel yield; TEP - total economic product.

from MPOB-NGA x AVROS marked the lowest S/F and $\mathrm{K} / \mathrm{F}$ and consequently exhibited the highest $\mathrm{M} / \mathrm{F}$ among the progenies. Conversely, PK 1885 from MPOB-CMR x AVROS with the highest value of $\mathrm{S} / \mathrm{F}$ and a K/F, showed the lowest $\mathrm{M} / \mathrm{F}$ at $68.21 \%$. Shell and kernel in oil palm may therefore influence mesocarp content (Noh et al., 2010).

The $\mathrm{F} / \mathrm{B}$ parameter is an estimate of the fruit set in an oil palm bunch. High amount of $F / B$ is essential for high $\mathrm{O} / \mathrm{B}$. The $\mathrm{O} / \mathrm{B}$ values is derived from $\mathrm{F} / \mathrm{B}, \mathrm{M} / \mathrm{F}$ and $\mathrm{O} / \mathrm{M}$ measurements (Corley and Tinker, 2016). PK 1867 progeny from MPOB-
NGA $x$ AVROS exhibited the highest $\mathrm{O} / \mathrm{B}$, which may be attributed to its high $\mathrm{M} / \mathrm{F}, \mathrm{F} / \mathrm{B}$ and $\mathrm{O} /$ $\mathrm{DM}$ mean values. When high $\mathrm{M} / \mathrm{F}, \mathrm{K} / \mathrm{B}$ and $\mathrm{F} / \mathrm{B}$ are coupled with high $\mathrm{O} / \mathrm{B}$ and $\mathrm{FFB}$, yields would likely be increased substantially (Kushairi et al., 1999).

The TEP was derived from the sum of OY and $60 \%$ of KY. Therefore, a high TEP value is contributed by bunches with a high content of mesocarp and kernel, suggesting the importance for maintaining a high F/B. From this study, PK 1858 (MPOBZRE $x$ AVROS) showed the highest OY and TEP, 
TABLE 7. ANOVA OF MPOB-NGA x AVROS, MPOB-CMR x AVROS AND MPOB-ZRE x AVROS Tenera PROGENIES FOR BUNCH QUALITY COMPONENTS

\begin{tabular}{|c|c|c|c|c|c|c|c|c|c|c|c|c|}
\hline \multirow[b]{2}{*}{ Materials } & \multirow[b]{2}{*}{$\begin{array}{c}\text { Source } \\
\text { of } \\
\text { variance }\end{array}$} & \multicolumn{11}{|c|}{ Mean square (2005-2013) } \\
\hline & & $d f$ & $\begin{array}{c}\mathbf{M} / \mathbf{F} \\
(\%)\end{array}$ & $\begin{array}{l}\mathbf{K} / \mathbf{F} \\
(\%)\end{array}$ & $\begin{array}{l}\mathrm{S} / \mathrm{F} \\
(\%)\end{array}$ & $\begin{array}{c}\text { O/DM } \\
(\%)\end{array}$ & $\begin{array}{l}\mathbf{F} / \mathbf{B} \\
(\%)\end{array}$ & $\begin{array}{l}\text { O/B } \\
(\%)\end{array}$ & $\begin{array}{r}\mathbf{K} / \mathbf{B} \\
(\%)\end{array}$ & $\begin{array}{c}\text { OY } \\
\left(\mathrm{kg} \mathrm{palm}^{-1}\right. \\
\left.\mathrm{yr}^{-1}\right)\end{array}$ & $\begin{array}{c}\mathrm{KY} \\
\left(\mathrm{kg} \mathrm{palm}^{-1}\right. \\
\left.\mathrm{yr}^{-1}\right)\end{array}$ & $\begin{array}{c}\text { TEP } \\
\left(\mathrm{kg} \mathrm{palm}^{-1}\right. \\
\left.\mathrm{yr}^{-1}\right)\end{array}$ \\
\hline \multirow{2}{*}{$\begin{array}{c}\text { MPOB-NGA } \\
\text { x AVROS }\end{array}$} & $\begin{array}{l}\text { Between } \\
\text { family }\end{array}$ & 3 & $309.92^{* *}$ & $4.50^{\mathrm{ns}}$ & $272.87^{* *}$ & $47.27^{*}$ & $64.55^{\mathrm{ns}}$ & $122.58^{* *}$ & $1.88^{\text {ns }}$ & $329.73^{* *}$ & $8.85^{\text {ns }}$ & $366.25^{* *}$ \\
\hline & $\begin{array}{l}\text { Within } \\
\text { family }\end{array}$ & 57 & 14.92 & 3.17 & 6.41 & 4.69 & 33.43 & 9.12 & 1.68 & 51.83 & 5.54 & 65.75 \\
\hline \multirow{2}{*}{$\begin{array}{c}\text { MPOB-CMR } \\
\text { x AVROS }\end{array}$} & $\begin{array}{l}\text { Between } \\
\text { family }\end{array}$ & 6 & $129.51^{* *}$ & $19.35^{* *}$ & $55.43^{* *}$ & $8.85^{\mathrm{ns}}$ & $76.80^{\text {ns }}$ & $5.84^{\mathrm{ns}}$ & $14.13^{* *}$ & $136.82^{* *}$ & $22.07^{*}$ & $155.37^{\mathrm{ns}}$ \\
\hline & $\begin{array}{l}\text { Within } \\
\text { family }\end{array}$ & 79 & 22.02 & 5.53 & 14.63 & 4.80 & 47.13 & 9.53 & 2.84 & 57.12 & 9.36 & 74.62 \\
\hline \multirow{2}{*}{$\begin{array}{c}\text { MPOB-ZRE } \\
\text { x AVROS }\end{array}$} & $\begin{array}{l}\text { Between } \\
\text { family }\end{array}$ & 2 & $12.06^{\mathrm{ns}}$ & $7.18^{\mathrm{ns}}$ & $3.07^{\mathrm{ns}}$ & $26.94^{* *}$ & $22.91^{\mathrm{ns}}$ & $16.98^{\mathrm{ns}}$ & $4.73^{\text {ns }}$ & $147.12^{*}$ & $4.78^{\text {ns }}$ & $123.61^{\mathrm{ns}}$ \\
\hline & $\begin{array}{l}\text { Within } \\
\text { family }\end{array}$ & 31 & 24.85 & 3.20 & 8.81 & 4.30 & 29.14 & 8.03 & 1.98 & 38.47 & 9.18 & 54.39 \\
\hline
\end{tabular}

Note: ${ }^{*}{ }^{* *}$, and ns indicate significant at $\mathrm{P} \leq 0.05, \mathrm{P} \leq 0.01$ and not significant, respectively; $\mathrm{M} / \mathrm{F}-\mathrm{mesocarp}$ to fruit ratio; $\mathrm{S} / \mathrm{F}-\mathrm{shell}$ to fruit ratio; K/F - kernel to fruit ratio; O/DM - oil to dry mesocarp ratio; F/ B - fruit to bunch ratio; O/B - oil to bunch ratio; K/B - kernel to bunch ratio; OY - oil yield; KY - kernel yield; TEP - total economic product.

that was likely contributed by the high FFB yield. At the other extreme, PK 1595 from MPOB-NGA x AVROS recorded the lowest TEP and lowest OY. On the other hand, progeny PK 1923 from MPOB-ZRE $x$ AVROS ranked the highest in terms of KY with $12.76 \mathrm{~kg}$ palm ${ }^{-1} \mathrm{yr}^{-1}$ or $1.8 \mathrm{t} \mathrm{ha}^{-1} \mathrm{yr}^{-1}$, far above the trial mean of $10.33 \mathrm{~kg}$ palm ${ }^{-1} \mathrm{yr}^{-1}$. The lowest KY was recorded from PK 1595 from MPOB-NGA x AVROS.

\section{Vegetative Traits}

Highly significant differences were observed between crosses for all vegetative traits, except for LL, LW and HTI (Table 9). Significant differences in only FP and DIA traits were observed between families for all three crosses (Table 10). MPOBNGA x AVROS and MPOB-CMR x AVROS crosses displayed significant differences between their progenies for all traits, indicating variations in these characters. On the other hand, MPOB-ZRE $x$ AVROS, no significant difference was observed between progenies for all traits, except FP and DIA, suggesting minimal variation in most of the vegetative traits between progenies of this cross.

MPOB-NGA x AVROS displayed the highest PCS, RL, LL, LN, LA, LAI and DIA (Table 11). MPOB-CMR x AVROS produced the smallest PCS, HTI and trunk diameter but had the longest leaflet width. Meanwhile, MPOB-ZRE x AVROS produced the highest average frond production of 27.41 frond palm ${ }^{-1} \mathrm{yr}^{-1}$ with a significantly shorter RL but displayed the lowest LAI and LN.

Besides FFB and bunch quality, other desirable vegetative and growth traits also contribute to yield performance (Teo et al., 2004). The numbers of fronds produced (FP trait) would determine the limit to bunch production since bunches develop at the frond axils of the palm (Noh et al., 2012). In this study, PK 1858 from MPOB-ZRE x AVROS was identified as the progeny which produced the highest FP and therefore also produced the highest BNO of 13.06 bunches palm ${ }^{-1} \mathrm{yr}^{-1}$. The lowest FP was produced by PK 1867 from MPOB-NGA x AVROS with BNO of only 10.25 bunches palm ${ }^{-1} \mathrm{yr}^{-1}$. Overall, the PCS ranged from 23.39 to $32.77 \mathrm{~cm}^{2}$ for all three crosses. PK 1867 from MPOB-NGA x AVROS registered the highest PCS while PK 1885 from MPOB-CMR x AVROS had the lowest PCS.

Palms with short RL are favourable in breeding and selection as they may be used to increase planting density per hectare. Progeny PK 1858 from MPOB-MPOB-ZRE x AVROS exhibited the shortest RL (5.08 m) while PK 1867 from MPOB-NGA x AVROS had the longest RL of $6.14 \mathrm{~m}$. The HTI trait is essential as it contributes to the economic life of an oil palm plantation. Progeny PK 1867 (MPOBNGA $x$ AVROS) and PK 1917 (MPOB-CMR x AVROS displayed the lowest HTI $\left(0.30 \mathrm{~m} \mathrm{yr}^{-1}\right)$. Low HTI may ease harvesting work.

\section{Heratibility Estimaes}

Broad-sense heritability estimates showed that $h^{2}{ }_{B}$ values for FFB and BNO were considered low $(<30 \%)$, at $20.56 \%$ and $23.22 \%$ respectively, though ABW has a higher heritability estimate (Table 12). Low heritability estimates for FFB yield and its components have also been reported for Deli dura 


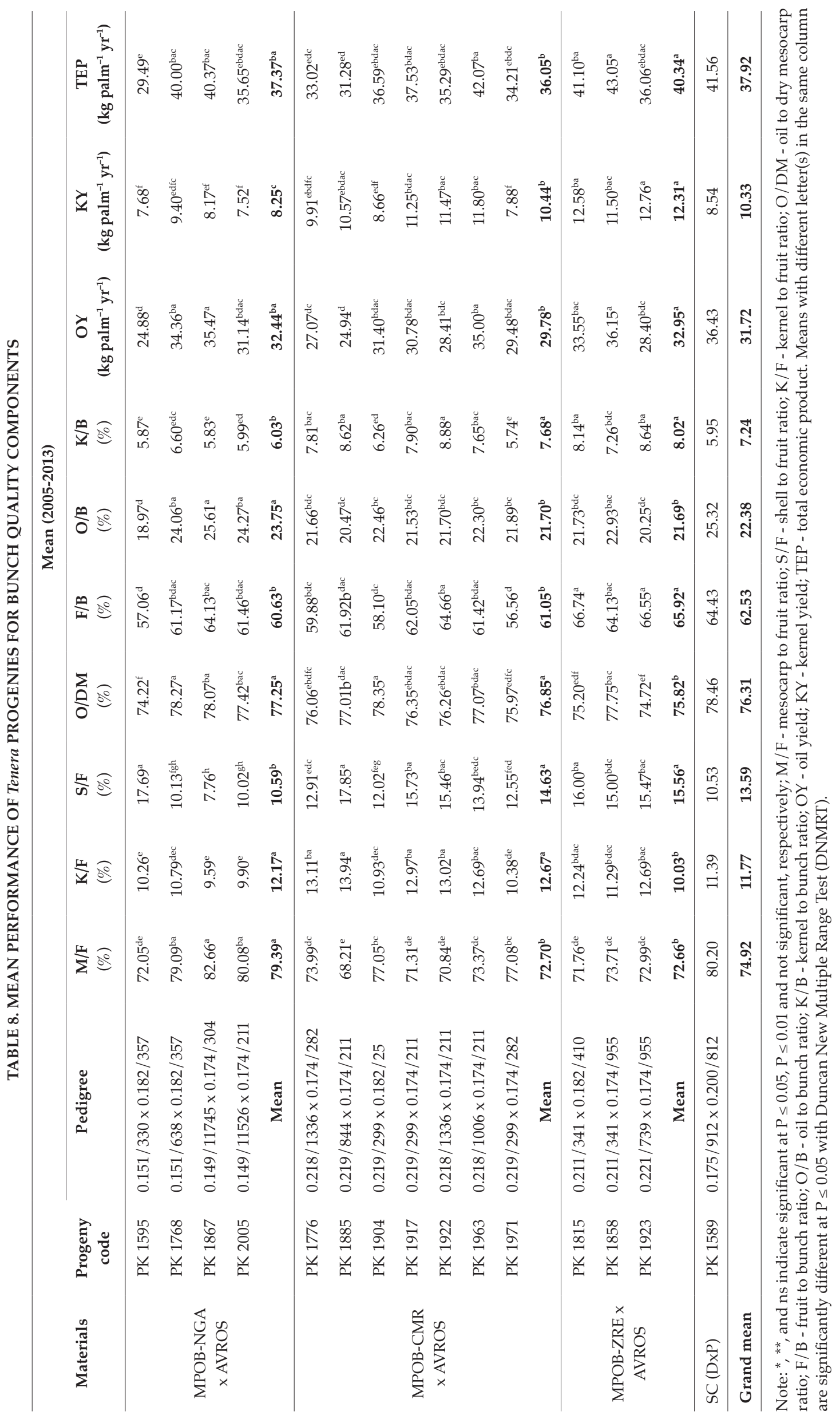


TABLE 9. ANOVA OF Tenera PROGENIES FOR VEGETATIVE CHARACTERS

\begin{tabular}{|c|c|c|c|c|c|c|c|c|c|c|c|}
\hline $\begin{array}{c}\text { Source of } \\
\text { variance }\end{array}$ & $d f$ & $\begin{array}{c}\text { FP } \\
\text { (frond } \\
\text { palm }^{-1} \mathrm{yr}^{-1} \text { ) }\end{array}$ & $\begin{array}{l}\text { PCS } \\
\left(\mathrm{cm}^{2}\right)\end{array}$ & $\begin{array}{l}\mathrm{RL} \\
(\mathrm{m})\end{array}$ & $\begin{array}{c}\mathrm{LL} \\
(\mathrm{cm})\end{array}$ & $\begin{array}{c}\mathrm{LW} \\
(\mathrm{cm})\end{array}$ & $\begin{array}{c}\text { LN } \\
\text { (No.) }\end{array}$ & $\begin{array}{c}\text { HTI } \\
\left(\mathrm{m} \mathrm{yr}^{-1}\right)\end{array}$ & $\begin{array}{c}\text { LA } \\
\left(\mathrm{m}^{2}\right)\end{array}$ & LAI & $\begin{array}{c}\text { DIA } \\
(\mathrm{m})\end{array}$ \\
\hline Between group & 2 & $36.55^{\star *}$ & $137.60^{* *}$ & $5.29^{* *}$ & $128.13^{\text {ns }}$ & $0.64^{\text {ns }}$ & $1313.01^{* *}$ & $0.006^{\mathrm{ns}}$ & $19.05^{* *}$ & $6.68^{\star *}$ & $0.02^{* *}$ \\
\hline Within group & 178 & 7.51 & 29.89 & 0.20 & 61.00 & 0.36 & 91.81 & 0.004 & 2.97 & 1.04 & 0.004 \\
\hline
\end{tabular}

Note: ${ }^{*}{ }^{* *}$ and $\mathrm{ns}$ indicate significant at $\mathrm{P} \leq 0.05, \mathrm{P} \leq 0.01$ and not-significant, respectively. FP - frond production; PCS - petiole crosssection; RL - rachis length; LL - leaflet length; LW - leaflet width; LN - leaflet number; HTI - height increment; LA - leaflet area; LAI - leaf area index; DIA - trunk diameter.

TABLE 10. ANOVA OF NGA x AVROS, CMR x AVROS AND ZRE x AVROS Tenera PROGENIES FOR VEGETATIVE CHARACTERS

\begin{tabular}{|c|c|c|c|c|c|c|c|c|c|c|c|c|}
\hline \multirow[b]{2}{*}{ Materials } & \multirow[b]{2}{*}{$\begin{array}{c}\text { Source } \\
\text { of } \\
\text { variance }\end{array}$} & \multirow[b]{2}{*}{$d f$} & \multicolumn{10}{|c|}{ Mean square (2005-2013) } \\
\hline & & & $\begin{array}{c}\text { FP } \\
\text { (frond } \\
\text { palm }^{-1} \mathrm{yr}^{-1} \text { ) }\end{array}$ & $\begin{array}{l}\text { PCS } \\
\left(\mathrm{cm}^{2}\right)\end{array}$ & $\begin{array}{l}\mathrm{RL} \\
(\mathrm{m})\end{array}$ & $\begin{array}{l}\mathrm{LL} \\
(\mathrm{cm})\end{array}$ & $\begin{array}{l}\mathrm{LW} \\
(\mathrm{cm})\end{array}$ & $\begin{array}{l}\text { LN } \\
\text { (No.) }\end{array}$ & $\underset{\left(\mathrm{m} \mathrm{yr}^{-1}\right)}{\mathrm{HTI}}$ & $\begin{array}{c}\text { LA } \\
\left(\mathrm{m}^{2}\right)\end{array}$ & LAI & $\begin{array}{l}\text { DIA } \\
(\mathrm{m})\end{array}$ \\
\hline \multirow{2}{*}{$\begin{array}{l}\text { MPOB-NGA } \\
\text { x AVROS }\end{array}$} & $\begin{array}{l}\text { Between } \\
\text { family }\end{array}$ & 3 & $29.43^{* *}$ & $147071^{* *}$ & $1.42^{* *}$ & $574.76^{* *}$ & $2.40^{* *}$ & $613.23^{* *}$ & $0.02^{* *}$ & $33.90^{* *}$ & $11.88^{* *}$ & $0.03^{* *}$ \\
\hline & $\begin{array}{l}\text { Within } \\
\text { family }\end{array}$ & 57 & 6.35 & 35.21 & 0.17 & 66.82 & 0.34 & 65.08 & 0.003 & 2.70 & 0.94 & 0.004 \\
\hline \multirow{2}{*}{$\begin{array}{c}\text { MPOB-CMR } \\
\text { x AVROS }\end{array}$} & $\begin{array}{l}\text { Between } \\
\text { family }\end{array}$ & 6 & $9.65^{* *}$ & $144.29^{* *}$ & $0.87^{* *}$ & $108.19^{* *}$ & $1.74^{* *}$ & $272.70^{* *}$ & $0.01^{*}$ & $8.97^{* *}$ & $3.14^{* *}$ & $0.02^{* *}$ \\
\hline & $\begin{array}{l}\text { Within } \\
\text { family }\end{array}$ & 79 & 7.14 & 18.90 & 0.15 & 38.89 & 0.23 & 85.21 & 0.03 & 1.99 & 0.70 & 0.002 \\
\hline \multirow{2}{*}{$\begin{array}{l}\text { MPOB-ZRE } \\
\text { x AVROS }\end{array}$} & $\begin{array}{l}\text { Between } \\
\text { family }\end{array}$ & 2 & $25.02^{*}$ & $3.07^{\mathrm{ns}}$ & $0.22^{\mathrm{ns}}$ & $1.81^{\mathrm{ns}}$ & $0.28^{\mathrm{ns}}$ & $36.45^{\mathrm{ns}}$ & $0.003^{\text {ns }}$ & $1.02^{\mathrm{ns}}$ & $0.36^{\mathrm{ns}}$ & $0.01^{* *}$ \\
\hline & $\begin{array}{l}\text { Within } \\
\text { family }\end{array}$ & 31 & 6.91 & 22.10 & 0.14 & 51.65 & 0.26 & 75.87 & 0.002 & 1.93 & 0.68 & 0.003 \\
\hline
\end{tabular}

Note: ${ }^{*}{ }^{* *}$, and ns indicate significant at $\mathrm{P} \leq 0.05, \mathrm{P} \leq 0.01$ and not-significant, respectively; FP - frond production; PCS - petiole crosssection; RL - rachis length; LL - leaflet length; LW - leaflet width; LN - leaflet number; HTI - height increment; LA - leaflet area; LAI - leaf area index; DIA - trunk diameter.

$\times$ MPOB-NGA pisifera population (Arolu et al., 2017; Noh et al., 2014). Heritability of yield and its component traits is very low due to the sensitive nature of the traits to environmental factors (Corley and Tinker, 2016). In bunch quality components, the broad-sense heritability estimates ranged from low to high (Table 13). The lowest was for F/ B followed by TEP and OY. On the other hand, high heritability estimates (>50\%) were obtained for S/F with $100 \%$, then $\mathrm{M} / \mathrm{F}(97.77 \%), \mathrm{K} / \mathrm{B}$ and $\mathrm{K} / \mathrm{F}$, indicating that these characters were highly heritable than FFB yield and its components. The results were in accordance to Hardon et al. (1985) as high heritability generally resulted from fruit characters such as M/F, S/F and $\mathrm{K} / \mathrm{F}$. Also, heritability estimates for vegetative traits varied from low $(27.53 \%)$ to high $(81.48 \%)$ (Table 14). Traits with high heritability estimates are generally more amenable for future breeding and selection (Noh et al., 2014). The highest $h^{2}{ }_{B}$ was scored by RL $(81.48 \%)$ followed by LA and LAI. High heritability values of above $50 \%$ were also observed for $\mathrm{LN}$, LW and DIA, indicating weak influence of the environment on the expression of these traits. This is in line with the findings of Arolu et al. (2017) for Deli dura x Nigerian pisifera population, implying that these traits may be used as the basis for selection of high yielding and compact palms.

\section{Correlation Analysis}

Analysis of correlation among the yield traits indicated that FFB and $\mathrm{BNO}$ showed a strong positive correlation $(\mathrm{r}=0.58, \quad \mathrm{P} \leq 0.01)$ while the correlation coefficient for FFB and ABW was 0.21 $(P \leq 0.01)$. This suggested that any positive increase in $\mathrm{BNO}$ and $\mathrm{ABW}$ will accelerate the improvement in FFB yield (Table 15). In contrast, the strong negative correlation $(r=-0.63, P \leq 0.01)$ between $B N O$ and $A B W$ suggested that selection for genotypes with high BNO would produce relatively lower ABW. Kushairi et al. (1999) also reported a similar observation when FFB yield exhibited significant positive correlations with $\mathrm{BNO}$ and $\mathrm{ABW}$ in the populations studied. The high correlation 


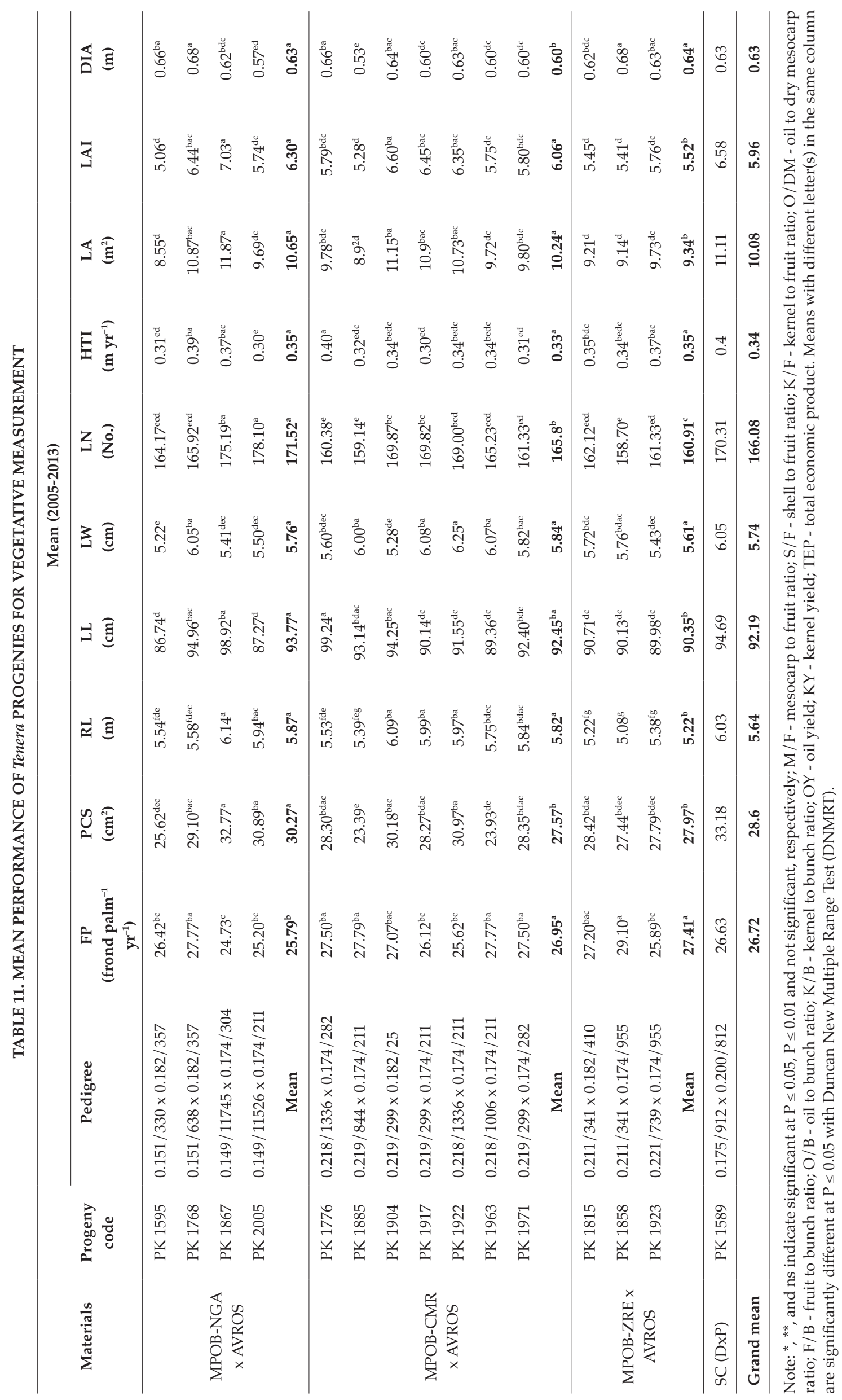


TABLE 12. MEAN SQUARES, VARIANCE COMPONENTS AND HERITABILITY ESTIMATES OF PROGENIES FOR YIELD AND YIELD COMPONENTS

\begin{tabular}{lcccc}
\hline Source of variance & $d f$ & FFB & BNO & ABW \\
\hline Between family & 13 & $2508.08^{* *}$ & $18.05^{* *}$ & $35.03^{* *}$ \\
Within family & 167 & 1016.90 & 6.70 & 9.95 \\
\hline$\sigma^{2 f}$ & & 116.50 & 0.88 & 1.95 \\
$\sigma^{2 \mathrm{wf}}$ & 1016.90 & 6.70 & 9.95 \\
\hline Total & 1133.40 & $\mathbf{7 . 5 8}$ & 11.90 \\
\hline Heritability (\%) & $\mathbf{2 0 . 5 6}$ & $\mathbf{2 3 . 2 2}$ & $\mathbf{3 2 . 7 7}$ \\
\hline
\end{tabular}

Note: ${ }^{*},{ }^{* *}$, and ns indicate significant at $\mathrm{P} \leq 0.05, \mathrm{P} \leq 0.01$ and not significant; respectively; FFB - fresh fruit bunch; BNO - bunch number; $\mathrm{ABW}$ - average bunch weight.

TABLE 13. MEANS SQUARES, VARIANCE COMPONENTS AND HERITABILITY ESTIMATES OF PROGENIES FOR BUNCH COMPONENTS

\begin{tabular}{|c|c|c|c|c|c|c|c|c|c|c|c|}
\hline Source of variance & $d f$ & $\mathbf{M} / \mathbf{F}$ & $\mathrm{K} / \mathrm{F}$ & $\mathrm{S} / \mathrm{F}$ & $\mathrm{O} / \mathrm{DM}$ & F/B & O/B & $\mathrm{K} / \mathrm{B}$ & OY & KY & TEP \\
\hline Between family & 13 & $272.76^{* *}$ & $31.01^{*}$ & $148.41^{* *}$ & $22.55^{\star *}$ & $108.40^{* *}$ & $46.76^{* *}$ & $17.39^{\star *}$ & $190.35^{* *}$ & $43.44^{\star *}$ & $209.80^{* *}$ \\
\hline Within family & 167 & 20.6 & 4.30 & 7.86 & 4.67 & 39.11 & 9.11 & 2.29 & 51.86 & 8.02 & 67.84 \\
\hline$\sigma^{2 f}$ & & 19.70 & 2.09 & 10.98 & 1.40 & 5.41 & 2.94 & 1.18 & 10.82 & 2.77 & 11.09 \\
\hline$\sigma^{2 \mathrm{wf}}$ & & 20.6 & 4.30 & 7.86 & 4.67 & 39.11 & 9.11 & 2.29 & 51.86 & 8.02 & 67.84 \\
\hline Total & & 40.3 & 6.38 & 18.84 & 6.07 & 44.52 & 12.05 & 3.47 & 62.68 & 10.79 & 78.93 \\
\hline Heritability (\%) & & 97.77 & 65.40 & 100 & 46.13 & 24.30 & 48.80 & 68.01 & 34.52 & 51.34 & 28.10 \\
\hline
\end{tabular}

Note: ${ }^{*}{ }^{* *}$ and $\mathrm{ns}$ indicate significant at $\mathrm{P} \leq 0.05, \mathrm{P} \leq 0.01$ and not significant, respectively; $\mathrm{M} / \mathrm{F}$ - mesocarp to fruit ratio; $\mathrm{K} / \mathrm{F}$ - kernel to fruit ratio; S/F - shell to fruit ratio; O/DM - oil to dry mesocarp ratio; F/ B - fruit to bunch ratio; O/B - oil to bunch ratio; K/B - kernel to bunch ratio; OY - oil yield; KY - kernel yield and TEP - total economic product; Estimates of heritability $>100 \%$ were recorded as $100 \%$.

TABLE 14. MEAN SQUARES, VARIANCE COMPONENTS AND HERITABILITY ESTIMATES OF PROGENIES FOR VEGETATIVE MEASUREMENT

\begin{tabular}{lccccccccccccccc}
\hline Source of variance & $d f$ & FP & PCS & RL & LL & LW & LN & HTI & LA & LAI & DIA \\
\hline Between family & 13 & $20.72^{* *}$ & $108.48^{* *}$ & $1.57^{* *}$ & $202.56^{* *}$ & $1.49^{* *}$ & $474.99^{* *}$ & $0.01^{* *}$ & $15.05^{* *}$ & $5.27^{* *}$ & $0.02^{* *}$ \\
Within family & 167 & 6.83 & 25.06 & 0.16 & 50.79 & 0.27 & 76.6 & 0.003 & 2.22 & 0.78 & 0.003 \\
\hline$\sigma^{2 f}$ & & 1.09 & 6.52 & 0.11 & 11.86 & 0.10 & 31.12 & 0.001 & 1.00 & 0.35 & 0.001 \\
$\sigma^{2 \mathrm{wf}}$ & & 6.83 & 25.06 & 0.16 & 50.79 & 0.27 & 76.6 & 0.003 & 2.22 & 0.78 & 0.003 \\
\hline Total & 7.92 & 31.58 & 0.27 & 62.65 & 0.37 & 107.72 & 0.004 & 3.22 & 1.13 & 0.004 \\
\hline Heritability (\%) & $\mathbf{2 7 . 5 3}$ & $\mathbf{4 1 . 2 9}$ & $\mathbf{8 1 . 4 8}$ & $\mathbf{3 7 . 8 6}$ & $\mathbf{5 4 . 0 5}$ & $\mathbf{5 7 . 7 8}$ & $\mathbf{3 7 . 8 4}$ & $\mathbf{6 2 . 1 1}$ & $\mathbf{6 1 . 9 5}$ & $\mathbf{5 0 . 0 0}$ \\
\hline
\end{tabular}

Note: ${ }^{*}{ }^{* *}$ and $\mathrm{ns}$ indicate significant at $\mathrm{P} \leq 0.05, \mathrm{P} \leq 0.01$ and not significant, respectively; FP - frond production; PCS - petiole cross section; RL - rachis length; LL - leaflet length; LW - leaflet width; LN - leaflet number; HTI - height increment; LA - leaflet area; LAI - leaf area index; DIA - trunk diameter.

coefficient for FFB yield and BNO suggested that the BNO component was the determinant for FFB yields. Therefore, selection of BNO may suffice for FFB yield improvement in oil palm.

For bunch quality components, positive correlations were observed between $\mathrm{OY}$ and FFB, $\mathrm{BNO}, \mathrm{ABW}, \mathrm{M} / \mathrm{F}, \mathrm{O} / \mathrm{DM}$ (Table 15). In addition,
OY showed strong positive correlations with TEP $(\mathrm{r}=0.73), \mathrm{O} / \mathrm{B}(\mathrm{r}=0.60), \mathrm{KY}(\mathrm{r}=0.52)$ and $\mathrm{O} / \mathrm{B}$ $(\mathrm{r}=0.60)$ traits. The results suggested that any positive increase in these traits would increase the OY of a palm. The significant negative correlations of $\mathrm{K} / \mathrm{F}(\mathrm{r}=-0.84)$ and S/F $(\mathrm{r}=-0.94)$ with $\mathrm{M} / \mathrm{F}$ is a supplementary source of variation for $\mathrm{O} / \mathrm{B}$. Both 


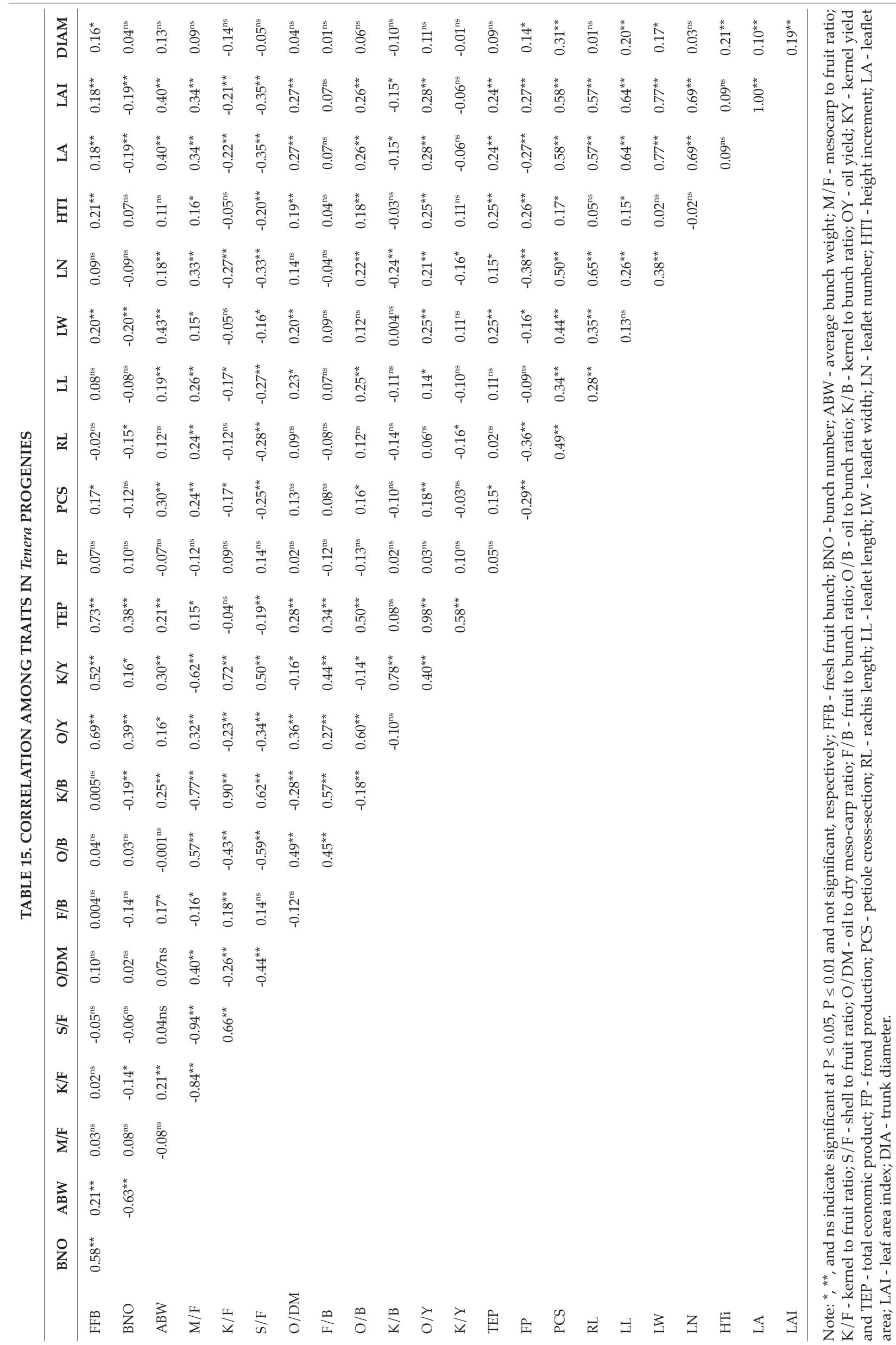


$\mathrm{K} / \mathrm{F}$ and $\mathrm{S} / \mathrm{F}$ contents of the fruit were affected mainly from their strong correlations with $\mathrm{M} / \mathrm{F}$. Increase in kernel size would increase the shell size and cause a reduction in the mesocarp content of a fruit. Thus, in order to be more effective in improving oil production, increase in $\mathrm{M} / \mathrm{F}$ or a decrease in the kernel and shell should be emphasised on (Okeye et al., 2009).

Positive but weak correlations were observed for vegetative traits PCS, LW, HTI, LAI and DIA with FFB yield (Table 15). This suggested that preferred vegetative charaters such as low HTI, PCS, DIA and RL would be a disadvantage as it might impair FFB production. Despite a positive correlation observed between HTI and FFB, selection for planting materials with high FFB but low height must continue (Isa et al., 2005). Moreover, OY was positively correlated with PCS, LL, LW, LN, HTI, LA and LAI. HTI showed a significant positive correlation with FP, PCS, LL and DIA.

\section{CONCLUSION}

Generally, the three progenies exhibited wide variability and genetic diversity for selection. MPOB-ZRE x AVROS cross was excellent for yield traits FFB and BNO. It also exhibited highest values in bunch quality components traits such as S/F, F/B, $\mathrm{KY}$ and TEP and was promising in the vegetative traits RL, LL and LN. On the other hand, MPOBNGA $x$ AVROS performed well in several bunch quality traits such as for M/F, S/F, O/B and O/DM. The MPOB-CMR $\times$ AVROS cross performed better in the PCS, HTI and DIA vegetative traits. Heritability of yield and its components was very low. Therefore, family or progeny selection may be a more suitable approach to improve these traits. However, high heritability was observed in most of the bunch quality and vegetative traits, implying that these traits could be used for the selection of high yielding and compact palms. PK 1858 from MPOB-ZRE $x$ AVROS may meet this purpose due to its high BNO, TEP, OY and FP, with lowest LN and RL. At the same time, PK 1867 from MPOB-NGA $x$ AVROS also showed promising $\mathrm{M} / \mathrm{F}, \mathrm{K} / \mathrm{F}, \mathrm{S} / \mathrm{F}, \mathrm{O} / \mathrm{B}$ values, which may contribute to high oil yield coupled with low PCS and HTI. The TxP crosses in this study was initated as a source of pisifera for commercial seed production. Therefore, the pisifera parent from PK 1858 and PK 1867 could be considered for progeny testing with advanced breeding populations such as Deli dura to reduce the dependence on AVROS as the main pollen source in current commercial DxP seed production.

\section{ACKNOWLEDGEMENT}

The authors would like to thank the Director-General of MPOB for permission to publish this article.

\section{REFERENCES}

Arolu, I W; Rafii, M Y; Marjuni, M; Hanafi, M M; Sulaiman, Z; Rahim, H A; Abidin, M I Z; Amiruddin, M D; Din, A K and Nookiah, R (2017). Breeding of high yielding and dwarf oil palm planting materials using Deli dura $\times$ Nigerian pisifera population. Euphytica, 213(7): 154.

Blaak, G; Sparnaaij, L D and Menendez, T (1963). Breeding and inheritance in the oil palm (Elaeis guineensis Jacq.). Part II. Methods of bunch quality of analysis. J.W. Afr. Inst. Oil Palm Res., 4: 146-155.

Breure, C J and Powell, M S (1987). The one-shot method of establishing growth parameters in oil palm. Proc. of the 1987 International Oil Palm Conference on Progress and Prospect. PORIM, Bangi. p. 203-209.

Corley, R H V and Breure, C J (1981). Measurements in Oil Palm Experiments. Internal Report, Unilever Plantations Group, London. p. 21.

Corley, R H V (2009). How much palm oil do we need? Environ. Sci. Policy, 12: 134-139.

Corley, R H V and Tinker, P B (2016). The Oil Palm. $5^{\text {th }}$ Edition. World Agricultural Series. Wiley Blackwell Publishers Ltd.

Fadila, A M; Norziha, A; Mohd Din, A; Rajanaidu, N and Kushairi, A (2016). Evaluation of bunch index in MPOB oil palm (Elaeis guineensis Jacq.) germplasm collection. J. Oil Palm Res. Vol. 28: 442-451.

Falconer, D S and Mackay, T F C (1996). Introduction to quantitative genetics. Trends in Genetics, 12(7): 280.

Hardon, J J; Rao, V and Rajanaidu, N (1985). A review of oil palm breeding. Progress in Plant Breeding (Russell, G E ed.). New York, Butterworth and Co. p. 139-163.

Hardon, J J (1974). The oil palm. Handbook of Plant Introduction in Tropical Crops. FAO Agricultural Studies 93, Rome.

Hardon, J J; Williams, C N and Watson, I (1969). Leaf area and yield in the oil palm in Malaya. Experimental Agriculture, 5(1): 25-32.

Idris, A; Kushairi, A; Ismail, $\mathrm{S}$ and Ariffin, D (2005). Selection for partial resistance in oil palm to Ganoderma basal stem rot. J. Oil Palm Res. Vol. 16: 12-18.

Isa, Z A; Mohd Din, A; Maizura, I; Noh, A; Kushairi, A and Rajanaidu, N (2006). PS12: Breeding population for high oleic acid palm oil. MPOB Information Series No. 313. 
Isa, Z A; Ong, K P; Norasyikin, I and Suboh, O (2008). Performance of MPOB-Nigeria Population 12 at Kulim - An update. Proc. of the $3^{\text {rd }}$ Seminar on Performance of PS1 and PS2 Materials and Elite Germplasm. MPOB, Bangi. p. 139-149.

Junaidah, J; Rafii, M Y; Chin, C W and Saleh, G (2011). Performance of tenera oil palm population derived from crosses between Deli dura and pisifera from different sources on inland soils. J. Oil Palm Res. Vol. 23(3): 1210-1221.

Kushairi, A; Rajanaidu, N; Jalani B S and Zakri, A H (1999). Agronomic performance and genetic variability of dura x pisifera progenies. J. Oil Palm Res. Vol. 11(2): 1-24.

Kushairi, A; Rajanaidu, N; Jalani, B S and Mohd Isa, Z A (1999). PORIM Series 1 - PORIM elite oil palm planting materials. PORIM Information Series No. 100.

Kushairi, A; Rajanaidu, N; Sundram, K and Maizura, I (2004). PS8: Vitamin E breeding population. MPOB Information Series No. 222.

Kushairi, A (2019). Malaysian oil palm industry performance 2018 and prospects for 2019. Paper presented at the Palm Economic Review \& Outlook (R\&O) Seminar 2019. Le Meridien, Putrajaya.

Lee, C H and Yeow, K H (1985). Progress in breeding and selection for seed production at HMPB Oil Palm Research Station. The Planter, 61: 18-31.

Maizura, I; Kushairi, A; Mohd Din, A; Noh, A; Marhalil, M; Wong, Y T and Sambanthamurthi, R (2008). PS13: Breeding populations selected for low lipase. MPOB Information Series No. 400.

Marhalil, M; Rafi, M Y; Arolu, I W; Noh, A; Mohd Din, A; Kushairi, A; Norziha, A; Rajanaidu, N; Latif, M A and Malek, M A (2013). Genetic variability in yield and vegetative traits in elite germplasm of MPOB-Nigerian dura $\times$ AVROS pisifera progenies. J. Food Agric Environ. Vol. 11(2): 515-519.

Noh, A; Rafii, M Y; Mohd Din, A; Kushairi, A; Norziha, A; Rajanaidu, N; Latif, M A and Malek, M A (2014). Variability and performance evaluation of introgressed Nigerian dura x Deli dura oil palm progenies. Genet. Mol. Res., 13(2): 2426-2437.

Noh, A; Rafii, M Y; Saleh, G; Kushairi, A and Latif, M A (2012). Genetic performance and general combining ability of oil palm Deli dura $\mathrm{x}$ AVROS pisifera tested on inland soils. The Scientific
World Journal. Article ID:792601. http://dx.doi. org / 10.1100/2012/792601

Noh, A; Rafii, M Y; Saleh, G and Kushairi, A (2010). Genetic performance of 40 Deli dura $\times$ AVROS pisifera full-sib families. J. Oil Palm Res. Vol. 22: 781-795.

Okoye, M N; Okwuagwu, C O and Uguru, MI (2009). Population improvement for fresh fruit bunch yield and yield components in oil palm (Elaeis guineensis Jacq.). American-Eurasian J. Scientific Research, 4(2): 59-63.

Rajanaidu, N; Kushairi, A; Mohd Din, A and Maizura, I (2008). A review on utilization and performance of MPOB PS series genetic materials. Proc. of the $3^{\text {rd }}$ Seminar on Performance of PS1 and PS2 Materials and Elite Germplasm. MPOB, Bangi. p. 3-25.

Rajanaidu, N; Jalani, B S; Soh, A C; Tek, J; Musa, B; Chin, C W and Yong, Y Y (1996). Performance of second generation of PORIM Nigerian material evaluated in Malaysia. Proc. of the 1996 PORIM International Palm Oil Congress: Competitiveness for the $21^{\text {st }}$ Century - Agriculture Conference. PORIM, Bangi. p. 32-45.

Rajanaidu, N; Kushairi, A; Rafii, M; Mohd Din, A; Maizura, I and Jalani, B S (2000). Oil palm breeding and genetic resources. Advances in Oil Palm Research (Yusof, B; Jalani, B S and Chan, K W eds.). MPOB, Bangi. p. 171-237.

Rajanaidu, N; Tan, Y P; Ong, E C and Lee, C H (1986). The performance of inter-origin commercial $\mathrm{D} \times \mathrm{P}$ planting material. Proc. of the International Workshop on Oil Palm Germplam and Utilization. PORIM, Bangi. p. 155-161.

Rajanaidu, N (1994). MPOB Oil Palm Genebank: Collection, Evaluation, Utilization and Conservation of Oil Palm Genetic Resources. MPOB, Bangi. p. 1-18.

Rao,V (1987). Important traits in oil palm selection. Proc. of the Colloquium on Breeding and Selection for Clonal Oil Palms. PORIM, Bangi. p. 21-33.

Rao, V; Soh, A C; Corley, R H V and Lee, C H (1983). A critical re-examination of the method of bunch quality analysis in oil palm breeding. PORIM Occasional Paper, 9: 1-28.

Teo, K W; Rao, V; Chia, C C and Lim, C C (2004). Performance of some pisiferas of Binga, Ekona, URT and Angolan origins: Part 2 - Fruit bunch yields, vegetative growth and physiological trait. J. Oil Palm Res. Vol. 16(1): 22-38. 